\begin{tabular}{|lcc|}
\hline & $\begin{array}{c}\text { Osmanlı Medeniyeti Araştırmaları Dergisi } \\
\text { Journal of Ottoman Civilization Studies }\end{array}$ \\
e-ISSN 2458-9519 & Cilt 6, Sayı 11, Ekim 2020 \& Vol 6, No 11, October 2020 \\
C2020 Telif Hakkı OSMED'e aittir & Article Types: Research Article \\
\hline DOI: 10.21021 /osmed.782546 & Makale Türü: Araştırma Makalesi & OSMED, 2020, 6(11): 184-199
\end{tabular}

\title{
Orta Anadolu'da Bir Yörük Köyü: Kömürcü
}

\author{
A Nomad Village in the Middle Anatolia: Kömürcü
}

\begin{abstract}
Ahmet KÖÇ*
$\ddot{\mathbf{O} z}$

Orta Anadolu'da Ankara'dan Kırşehir'e giden eski yol üzerinde bulunan Kömürcü Mahallesi/köyü idari açıdan bugün Çankaya İlçesine bağlıdır. Osmanlı devrinde şehre bir günlük mesafedeki bu bölgede yolcuların konaklaması için Yakub Abdal ve Ahi Çomak Tekkeleri kurulmuştur. Söz konusu Yakup Abdal Tekkesi; Kömürcü, Evciler, Tekke (Ahi Çomak) yol güzergahı üzerindedir.

Tipik Anadolu köyleri gibi verimsiz ve yetersiz arazilerde, hayvancılığın sınırlı yapılabildiği bölgede kurulmuş olan, bugün büyüyen metropol Ankara'nın hemen yanı başındadır. Anadolu'nun ücra köylerinden pek farkı olmayan Kömürcü Karyesi'nin, XIX. yüzyıldaki temettuat ve nüfus defterlerinden hareketle vaziyetini ortaya koymak çalışmanın temel amacıdır. XIX. yüzyılda Elmadağ’ın arka yamacındaki köyün tarım ve hayvancılık imkanlarının kısıtlılığ1, köylülerin günlük işlerde çalışmak üzere yakın köylere gidip gelmelerine yol açmıştır. Temettuat defteri çerçevesinde köylünün durumu çeşitli yönlerden ele alınarak, zorlu şartlar altında köylünün alternatifler geliştirdiğini göstermektedir. Buna göre kimi zaman günlük, kimi zaman mevsimlik işlerde çalışmak üzere giden köylüler mali durumlarını güçlendirmeye çalışmışlardır. Bu araştırmada bütüncül tarihçiliğin bir parçası olarak ülkemizde fazla geliş(e)meyen mahalli tarih çalışması küçük bir köy olan Kömürcü özelinde ele alınmıştır.
\end{abstract}

Anahtar Kelimeler: Osmanlı, Anadolu Ankara, Çankaya, Kömürcü, Temettuat, Yörük

\begin{abstract}
The Kömürcü neighborhood/village, which is located on the old road from Ankara to Kırşehir in Central Anatolia, is connected to Çankaya District from the administrative point of view. Yakub Abdal and Ahi Çomak Dervish Lodges were established for the passengers to stay in this region, which is one day away from the city during the Ottoman period. Yakub Abdal Dervish Lodge in question is located on the Kömürcü, Evciler, Tekke (Ahi Çomak) road route.

Kömürcü village; it has been established in a region where animal husbandry can be limited in inefficient and inadequate lands such as typical Anatolian villages. The village today is right next to the growing metropolis of Ankara. The main purpose of the study is to reveal the situation of Kömürcü village, which is not much different from the remote villages of Anatolia, from the 19th century in the form of the temettuat and population registers. In the 19th century, the limited agricultural and livestock facilities of the village on the back slope of Elmadag led the villagers to move to nearby villages to work in daily work. The situation of the villagers was discussed in various aspects within the framework of the temettuat register. Temettuat registers show that the villager has developed alternatives under difficult conditions. Accordingly, the peasants, who work in daily or seasonal jobs, tried to strengthen their financial situation. In this study, as a part of holistic historiography, the local history study which is not very developed in our country has been handled in a small village called Kömürcü.
\end{abstract}

Keywords: Ottoman, Anatolia, Ankara, Çankaya, Kömürcü, Temettuat, Nomad.

\footnotetext{
*(Prof. Dr.); Akdemiz Üniversitesi, ahmetkoc@akdeniz.edu.tr; ORCID:orcid.org/0000-0002-8819-8095 Kaynak Gösterme: Köç, A. "Orta Anadolu’da Bir Yörük Köyü: Kömürcü". Osmanlı Medeniyeti Araştırmaları Dergisi, 6 (2020): 184199.
} 


\section{Giriş}

Çalışmamızın temel kaynağ 1 Kömürcü karyesi temettuat ${ }^{1}$ ve nüfus defterleridir ${ }^{2}$. İncelemiş olduğumuz defterin düzenlenme sistemi, alışlagelmiş temettuat defterlerinde olduğu gibidir ${ }^{3}$. Genellikle bir sayfada üç haneye ait bilgiler kaydedilmiştir. Defterde önce hane numarası belirtilmiş ve hemen yanında da hane reisinin şöhreti veya sülale adı belirtildikten sonra kendi ismi yazılmıştır. Hane reisinin üst kısmında dikey olarak, hane reisinin mesleği ve durumunu açıklayan kısa bilgi, sene-i sâbıkada vergi-yü mahsûsâdan bir senede vermiş olduğu ifadeleriyle kuruş cinsinden ne kadar vergi verdiği belirtilmiştir. Yine bu bilgilere paralel biçimde 'aşâr ve rüsûm olarak sene-i sâbıkada vermiş olduğu ifadelerinden sonra verilen öşürler ve hayvancılık vergisi "guruş" cinsinden yazılmıştır.

Hane reisinin isminin altındaki satıra, şahsın menkul ve gayrimenkul mal varlığı (mezrû tarla, sağmal inek, keçi, yoz koyun, kuzu, oğlak) ile bunlardan bir önceki yıl olan H.1260/1244 senesi ile içinde bulunulan H.1261/M.1245 senesine ait tahmini gelir kaydedilmiştir. Bütün bu ayrıntılardan sonra en alt satıra menkul ve gayrimenkul servetten elde edilen toplam geliri mecmû ' indan bir senede tahminen temettuâtı şeklinde kaydedilirken bu son satırda yukarıda belirtilen gelir kaynaklarının dışında hane reisinin başkaca bir gelir kaynağı varsa (ticaret, zuhurat vb.) ayrıntıya girilmeden yazılmıştır. Böylece hane reisinin toplam geliri tespit edilerek devlete vereceği vergi miktarının belirlenmesi sağlanmak amaçlanmıştır.

Hane reislerinin isimleri yazılırken, diğer defter örneklerindeki gibi varsa lakap ve unvanları da yazılmıştır. Defterlerin tanzim edilme sebebi, vergi miktarını ortaya koymak olduğundan kişilerin malları ve gelirleri hane reisinin adının altına kaydedilmiştir ${ }^{4}$. Bunlardan başka gelir kaynaklarının yanı sıra hane reisinin mesleklerinin de kaydedilmiş olması, meslek gruplarının bölgedeki dağılımını çıkarmak ve onların malvarlıklarına dair fikir sahibi olmayı kolaylaştırmaktadır.

Çalışmamızdaki bir diğer kaynak nüfus defteridir ${ }^{5}$. Kömürcü köyüne ait nüfus defteri müstakil bir defter olarak tutulmamıştır. Bala Nahiyesi'ne ait defterde köye ait sayfalardan istifade edilmiştir. Nüfus defterlerindeki kayıt sistemi temettuat defterlerinde olduğu gibi hane sistemi ile kaydedilmiştir. Her bir hanenin en yaşlı erkek üyesi hane reisi olarak kaydedilmiş ve diğer erkek bireyler bu hane reisine göre "oğlu", "torunu", "biraderi” ifadeleri ile kaydedilmiştir. Hane reislerinin sülale adları yazılmış, hanedeki diğer kişilerin sadece isimleri ve yaşları yazılmıştır. Ayrıca hanedeki yaşayan erkeklerin boy, sakal, bıyık gibi özellikleri de kaydedilmiştir.

\footnotetext{
1 Tanzimat Fermanıyla birlikte vergi düzenlemesi yapılarak vergilerin bir araya toplandığı yeni bir malî sistem ortaya çıtı. Devrin kaynaklarında herkesin kazancıyla mütenâsib olarak temettu vergisi oluşturulduğu ifade edilmiştir. Devlet idaresinde H.1261 yılında yapılan malî değişiklikle Müslümanların vergi kayıtlarının tutulmasında muhtar-ı evvel ve muhtar-ı sânîlerle köy imamları; gayrimüslimlerin yazılmasında ise kocabaşlarla, papazlara sorumluluk yüklenerek, bunların defterleri mühürlemesi istenmiştir. Ancak Temettuât defterleri serisindeki bütün defterlerin sonunda mühür bulmak mümkün değildir. Bazılarında bende kelimesi yazılıp bırakılmıştır. Bu da defterlerin hepsinin orijinal olmayıp bir kısmının muhtemelen merkezde çıkarılmış suretler olduğunu akla getirmektedir. Bk. M. S. Kütükoğlu, "Osmanlı Sosyal ve İktisadî Tarihi Kaynaklarından Temettüât Defterleri”, Belleten, LIX, (1995), s. 395.

2 II. Mahmud devrinde ülke toprakları dahilindeki vergi mükellefleri ile askere alınabilecek şahısların tam sayısını tespit edebilmek için sayım yaptırılmıştır. Böylece ülkedeki müslim ve gayrimüslim nüfus ayrı ayrı sayılmış, defterleri de ayrı tutulmuştur. Bütün sancak, kaza ve köylerde halk İslâm ve Reâyâ (Gayrimüslim) olarak iki gruba ayrılmıştır. Bk. H. Çınar- í. Kıvrım; 1842 Tarihli Çubuk Kazası Nüfus Defteri, Çubuk Belediyesi Yayınları, Ankara 2018, s. 13-14.

3 Kömürcü Köyü’ne ait temettuat defteri BOA.ML.VRD.TMD.d No: 292 künyesi ile Cumhurbaşkanlığı Osmanlı Arşivlerinde kayıtlıdır. Defterin kapak sayfasında "Tâbi-i Kasaba-i Bala der-Kazâ-i Ankara; 26" ifadesi yer almaktadır. Defter toplam 9 sayfa olup, 29 hane kayıtlıdır.

${ }^{4}$ H. Çınar-i. Kıvrım, age, s.14.

${ }^{5}$ Kaynak olarak kullandığımız nüfus defteri Bala Nahiyesi'ne ait 1768 Nolu Nüfus defterinin 183-185 sayfalarında yer alan Karye-i Kömürcü bölümüdür. Defterde satırlar halinde tutulmuş ve her bir satıra bir hane kaydedilmiştir. Defterde köyde yaşayan erkekler kaydedilmiş olup, 75 erkek nüfusun kaydı bulunmaktadır. Bk. BOA. NFS. d. 1768.
} 
Coğrafi mekan olarak Kömürcü Köyü; Elmadağ’ın güney plato yamacında olup etrafında Evciler, Karahasanlı, Tohumlar ve Yakub Abdal Mahalleleri vardır ${ }^{6}$. Köyün kullandığı Karahasan Yaylası, hemen yakınındaki Karahasanlı Köyü'nden ayrıdır. Bu durumda insanlar birlikte yaşıyorlardı da bu mahalleler sonradan $\mathrm{m} 1$ ayrıld1? Sorusuna cevap bulmak gerekmektedir.

\section{Köyün Nüfus Özellikleri}

Osmanlı Devleti'nde modern anlamda "nüfus sayımı" addedilebilecek bir sayım yapılmamıştır. Ancak, toprak yazımı ve vergi mükelleflerinin tespiti için hazırlanan Tapu Tahrir defterleri Osmanlı Devleti'nin nüfusunu tespit etmek için en eski ve en güvenilir kaynaklardır. Esas olarak XV. ve XVI. yüzyılları kapsayan ama XVII. yüzyılda da bazı örneklerini gördügümüz bu defterler Osmanlı devletinde timar sisteminin uygulandığı topraklardaki vergilendirilebilir ekonomik etkinliklerin ve insan kaynaklarının yerinde tespit ve kaydını içermesi açısından bizlere istatistiksel analize uygun en zengin sayısal verileri sunmaktadırlar ${ }^{7}$.

XIX. yüzyılın sonlarına kadar Osmanlı Devleti'nde gerçek anlamda, erkek ve kadınların bir arada sayıldığı nüfus sayımı yapılmamıştır. Ancak bu dönemden sonra Osmanlı Devleti'nde yapılan ilk önemli nüfus sayımı II. Mahmut dönemindedir. II. Mahmut döneminde, idari, askeri ve mali alanlarda yapılan reformlar yeni bir nüfus sayımını gündeme getirmiştir. Nitekim H.1246-47/M.1831 yılında Osmanlı Devleti'nin genelinde yeni oluşturulan askeri düzeni sağlam bir temele oturtabilmek ve ülkenin asker potansiyelini tespit edebilmek amacıyla, sadece erkek nüfusun sayıldığı bir nüfus sayımı yapılmıştır ${ }^{8}$. Bu dönemde Kömürcü Köyü'nün erkek nüfusu 75'tir. Kadın ve erkeklerin eşit olduğu kabul edilirse, köyün nüfusunun 150 civarında olduğunu tahmin etmek mümkündür. Aynı kayıtlarda köyün hane sayısı 29 olarak belirtilmiştir. Bu durumda köyde XIX. yüzyıl ortalarında bir hanede ortalama 6 kişinin yaşadığı ortaya çıkmaktadır'.

Tanzimat'ın ilanıyla birlikte, mali reformlar çerçevesinde bu kez temettuat sayımlarına gidilmiştir. Bu temettuat sayımının da gerçek amacının mali olması, nüfus bilgileri bakımından dolaylı bilgiler vermektedir. Çünkü Temettuat Defterleri herhangi bir istatistiki bilgi derlemek için hazırlanmamıştır. Bunların asıl hazırlanış amacı, Tanzimat olarak adlandırılan geniş kapsamlı bir reform hareketinin bir yan ürünü olarak ortaya çıkmıştır. Bu sebeple, temettuat defterlerinde gerçek bir nüfusu elde etmek mümkün değildir. Çünkü bu defterlerde sadece hane sayıları bulunmaktadır. Sayımların hane esasına göre yapılmış olması, temettuat defterlerinin ihtiva ettiği bilgileri daha da zenginleștirmekte ve sayımlara adeta bir istatistik anket özelliği kazandırmaktadır. Kömürcü Köyü'ne ait temettuat defterinde, köyün hane sayısı 29'dur. H.1259-60/M.1844-45 yılı nüfus kayıtlarına bakılarak, bu tarihte köyün nüfusunun 150 kişi civarında olmalıdır ${ }^{10}$.

Osmanlı nüfus ve temettuat defterleri köyde yaşayan kişilerin isimlerini tespit etmede birinci derecede önemli kaynaklardır. Temettuat defterlerinde genellikle kişilerin kendi isimlerinin yanında babalarının isimleri de yazılmıştır. Nüfus defterleri ise bu anlamda daha geniş bilgiler ihtiva etmektedir. Çünkü nüfus defterlerinde hane reislerinin isimleri, babalarının isimleri ve hanede yaşayan diğer erkek nüfusun isimleri yer almaktadır. Çalışmamızda da isimlerin tespitinde nüfus defterlerinden elde edilen veriler kullanılmıştır.

\footnotetext{
${ }^{6}$ Osmanlı devrinde bu köy, yakınında bulunan Yakub Abdal Tekkesi'yle de bilinmektedir. Bk. A. Köç, "Ankara'da Yakub Abdal Zaviyesi'nin İdari Sorunları", Gazi Akademik Bakış XI, Ankara 2012, s. 213.

7 H. İnalcık- Ş. Pamuk, Osmanlı Devleti'nde Bilgi ve İstatistik, 2001, s. 35-50.

8 H. Erdoğan, 2005, "820 Numaralı Temettuat Defterine Göre Tanzimat’ın İlk Yıllarında Mucur ve Hacıbektaş’ın Demografik Yapısı ve Sosyal Durumu" Gazi Üniversitesi Kırşehir Eğitim. Fakültesi Dergisi 6(1), s. 96.

${ }^{9}$ BOA. NFS. d. 1768.

10 T. Güran, “XIX. yüzyıl Temettuat Tahrirleri”, Osmanlı Devleti’nde Bilgi ve İstatistik, 2000, s. 79.
} 
Kömürcü köyünün 1842 y1lı nüfus defterine göre köyde yaşayan 75 erkekler, 19 farklı isim kullanmaktadir ${ }^{11}$.

\begin{tabular}{|} 
Tablo-1: Nüfus Defterine Göre Kömürcü Köyünde Kullanılan İsimler ve Oranları \\
\hline $\mathbf{N o}$ & Kullanılan İsim & Sayıs & Yüzdelik Oranı (\%) \\
\hline $\mathbf{1}$ & Mehmet & 12 & 16,00 \\
\hline $\mathbf{2}$ & Ali & 10 & 13,34 \\
\hline $\mathbf{3}$ & Mustafa & 8 & 10,67 \\
\hline $\mathbf{4}$ & Hüseyin & 7 & 9,34 \\
\hline $\mathbf{5}$ & Osman & 7 & 9,34 \\
\hline $\mathbf{6}$ & İbrahim & 5 & 6,67 \\
\hline $\mathbf{7}$ & Ahmed & 4 & 5,34 \\
\hline $\mathbf{8}$ & Hasan & 3 & 4,00 \\
\hline $\mathbf{9}$ & İsmail & 3 & 4,00 \\
\hline $\mathbf{1 0}$ & Memiş & 3 & 4.00 \\
\hline $\mathbf{1 1}$ & Seyyid & 3 & 4,00 \\
\hline $\mathbf{1 2}$ & Abidin & 2 & 2,65 \\
\hline $\mathbf{1 3}$ & Ömer & 2 & 2,65 \\
\hline $\mathbf{1 4}$ & Abdullah & 1 & 1,32 \\
\hline $\mathbf{1 5}$ & Dede & 1 & 1,32 \\
\hline $\mathbf{1 6}$ & Halil & 1 & 1,32 \\
\hline $\mathbf{1 7}$ & Musa & 1 & 1,32 \\
\hline $\mathbf{1 8}$ & Talip & 1 & 1,32 \\
\hline $\mathbf{1 9}$ & Yusuf & 1 & 1,32 \\
\hline
\end{tabular}

Köyde yaygın olarak kullanılan isimler, köyün dini ve etnik yapısını ortaya koymak için önemlidir. Köydeki isimler incelendiği zaman genellikle dini özellik taşıdığını tespit etmek mümkündür. Bu bağlamda en çok kullanılan isimlerin başında; Mehmed ${ }^{12}$, Ali, Mustafa ve Hüseyin vardır. Türk toplumunda bu isimler birçok yörede yaygın bir biçimde kullanılmaktadır. ${ }^{13}$ Bahsedilen isimlerin fazla konması, Anadolu insanının Peygambere olan sayg1 ve sevgisinin bir ifadesi olarak kabul edilebilir. Defterde Mehmed isminin kullanılma oran $1 \%$ 16'dır. Bu ismi takip eden Ali isminin kullanılma oran1 \% 13.34, Mustafa isminin kullanılma oranı \% 10.67, Hüseyin ve Osman isimlerinin kullanılma oranı ise \% 9,34'tür.

Köydeki kullanılan diğer isimler kullanılma oranları ise İbrahim \% 6.67, Ahmed \% 5.34, Hasan, İsmail, Memiş ve Seyyid isimleri \% 4 olarak kullanılmıştır. Abidin ve Ömer isimleri 2'şer defa kullanılmış olup, bunların oran1 \% 2.65'tir. Abdullah, Dede, Halil, Musa, Talip ve Yusuf isimleri ise birer defa

\footnotetext{
${ }^{11}$ BOA. NFS.d. No: 1768.

12 Mehmed ismi, Muhammed isminin Anadolu'da kullanılan şeklidir. Defterlerde bu isim şeddesiz olarak kullanıldığı için "Mehmed" olarak kabul edilmiştir.

${ }^{13}$ Mehmet ismi hala en yaygın kullanılan isimlerden bir tanesidir. Nüfus İstatistikleri Daire Başkanlığı'nın verilerine göre en fazla kullanılan 50 ismin birincisini Mehmet oluşturmaktadır. Bu ismi, Mustafa, Ahmet, Ali ve Hüseyin teşkil etmektedir. Bu isimleri incelediğimizde Kömürcü Köyü’nde 1844 yılında da en çok kullanılan isimler olduğu görülür.
} 
kullanılmıştır. Burada dikkat çeken isim "Dede" ismidir"14. Genellikle Anadolu' da yaygın olarak kullanılan bir isim değildir.

Kullanılan bu isimlere bakıldığında; Dede isminin haricindeki isimlerin tamamının Arapça kökenli olduğu ve Türklerin İslamiyet'i benimsedikten sonra, dinin etkisi ile alınan isimler olduğu görülmektedir. $\mathrm{Bu}$ bağlamda, Mehmed, Ahmed ve Mustafa isimleri Hz. Muhammed'in kullandığ isimlerdendir. Ali, Hüseyin ve Hasan isimleri Hz. Muhammed'in ehl-i beytinin isimleridir. Yine İslam'in ilk dört halifelerinden olan Hz. Ömer ve Hz. Osman isimleri köyde tercih edilen isimler arasındadır. Bunların haricinde İbrahim, İsmail, Musa ve Yusuf isimleri ise Kuran-1 Kerim'de isimleri zikredilen peygamberlerin isimlerinden esinlenerek konulmuş olan isimlerdir.

Toplum hayatımızda önemli bir yer tutan sülale isimleri ve lakaplar; Cumhuriyetin İlanı'ndan sonra yani 26 Kasım 1934 tarihinde kabul edilen soyadı kanunuyla tarihe karışmıştır. Ancak, Anadolu'da özellikle küçük yerleşim yerlerinde halk, birbirini tanımlarken gayriresmi de olsa sülale isimlerini kullanılmaya devam etmektedir.

Soyadı Kanununun kabulünden önce, soyadı gibi, isimden önce kullanılan sülale isimleri, bugün her ne kadar resmen kullanılmasa bile, geçmiş ile günümüz arasında bir bağ oluşturmaktadır. Sülale isimlerinden bazıları soy isim olarak köyde devam etmektedir. Çünkü sülale isimlerinden yola çıkılarak kimi ailelerin şecerelerini belki erken dönemlerden beri bu topraklarda olduklarını daha da önemlisi dedelerinin nasıl ve kimler olduğunu anlayabilme imkanı olacaktır.

\section{Tablo-2: Kömürcü Köyü Sülaleleri}

\begin{tabular}{|l|c|}
\hline Sülale Adı & Sayısı \\
\hline Amancı Oğulları & 1 \\
\hline Aziz Oğulları & 1 \\
\hline Bektaş Oğulları & 1 \\
\hline Çakır Oğulları & 1 \\
\hline Deli İbrahim Oğulları & 1 \\
\hline Emir Oğulları & 1 \\
\hline Göde Oğulları & 1 \\
\hline Hacı Oğulları & 1 \\
\hline İsmail Oğulları & 1 \\
\hline Karenpe Oğulları & 1 \\
\hline Koca Mustafa Oğulları & 1 \\
\hline Koca Oğlan Oğulları & 1 \\
\hline Küçük Mehmed Oğulları & 1 \\
\hline Mahmud Oğulları & 1 \\
\hline Musa Oğulları & 1 \\
\hline Tirak Oğulları & 1 \\
\hline Topal Dede Oğulları & 1 \\
\hline Osman Oğulları & 2 \\
\hline & \\
\hline
\end{tabular}

\footnotetext{
${ }^{14}$ Mehmet Kılıç, Kömürcü'den Kayaş’a isimli eserinde; adı geçen Dede isimli kişinin oğlunun isminin Mehmet olduğundan bahseder. Köyde bu kişiye Dede'nin Mehmet dendiğinden bahsedildiğini aktarmaktadır. Muhtemelen bu dedelik unvanı alevi din adamları için kullanılıyordu. Bk. M. Kılıç, Kömürcü'den Kayaş'a, s. 43.
} 


\begin{tabular}{|l|l|}
\hline Süleyman Oğulları & 2 \\
\hline Hasan Oğulları & 4 \\
\hline Abidin Oğulları & 5 \\
\hline
\end{tabular}

Temettuat defterinde köyde yaşayan hane reislerinin sülaleleri yazılmıştır. Buradan yola çıkarak köydeki sülaleleri tespit etmek mümkün olmuştur. Bu sülale adlarına bakıldığı zaman genellikle isimlerden oluştuğu görülmektedir. Bunun yanında ismin başında bir sıfat olarak gelen sülale adları da bulunmaktadır. Amancı Oğlu, Tirak Oğlu ve Karenpe Oğlu gibi anlamlandırılamayan sülale adları da vardır. Sadece sıfat veya bir unvandan kaynaklanan sülale adları mevcut olup, bunlar Çakır Oğlu, Emir Oğlu, Göde Oğlu ve Hacı Oğlu'dur.

Köydeki en kalabalık sülalenin Abidin Oğulları olduğu tespit edilmiş olup, bu sülaleye ait 5 hane bulunmaktadır. Bunu Hasan Oğulları Sülalesi takip etmektedir. Bu sülaleye mensup hane sayısı ise 4'tür. Osman Oğulları ve Süleyman Oğulları sülalelerine mensup hane sayıları ise 2'şerdir. Diğer bütün sülaleler birer hanedir.

\section{Köylülerin Meslekleri ve Vergileri}

Temetuat defterinde hane reislerinin meslekleri açıkça yazılmıştır. Bu defterde de, 29 hane reisinden 27 hane reisinin mesleği kaydedilmiştir. Bunlardan bir hane reisinin "vefat ettiği" belirtilmiş ve bu sebeple meslek bölümü boş bırakılmıştır. Bir hane reisinin ise hasta olduğu kaydedilmiştir. Köyde kaydedilen meslek çeşidi 4'tür. Temettuat kayıtları verilerine göre, Kömürcü Köyü’nde M.1844 yılında yaşayan hane reislerinin meslekleri genellikle tarım üzerinedir. ${ }^{15}$

Bu şekilde mesleği erbâb-ı zirâ'at olarak kaydedilen hane reislerinin sayıs 18 olup, toplam mesleklere oranı \% 66,6'dır. Bu durum, köyün büyük bir çoğunluğunun tarımla meşgul olduğu ve geçimini tarımdan elde ettiğini göstermektedir. İki hane reisinin mesleği ise, hizmetkar olarak kaydedilmiştir. Ancak, bunların ne tür iş yaptığı hususunda herhangi bir bilgi bulunmamaktadır. Köyün geçim kaynağının tarım olmasından yola çıkarak, bunların tarımda çalışan kişiler olduğunu da tahmin etmek mümkündür. Bundan başka 3 hane reisinin mesleği çoban olarak kaydedilmiştir. Bunların oranı ise \% 11'dir. Köydeki üç hane reisi ise trgat olarak kaydedilmiştir. Irgat, toprağa bağlı işçilere verilen addır. Bunların toplam mesleklere oranı da \% 11 olarak hesaplanmıştır. Başka birinin işinde çalışan çoban, hizmetkar ve irgatlar köylünün günlük işler için yakın mesafelere gidip geldiklerini göstermektedir. Diğer taraftan bir hane reisisin mesleği de kizir olarak belirtilmiştir ${ }^{16}$. Anadolu'nun muhtelif yerlerinde farklı anlamlarda kullanılan kizir, köy muhtarı emrindeki köy bekçisi, köy kahyası ve vergi toplama memuru şeklinde kullanılabilmektedir ${ }^{17}$. Oysa Kömürcü’de kizir kavramı, daha çok muhtar emrinde çalışan bekçiye denmektedir.

Köylülerin civar köylerde yevmiyeyle ve genellikle bir sezon için varlıklı birinin yanında hizmetkar olarak çalıştıkları anlaşılmaktadır. Kömürcü Köyü'nde buna hizmetkar durmak denmektedir. Hizmetkar duran kişiler ağanın yanında işe bahar mevsiminde başlayıp, Kasım ya da Aralık ayına kadar devam ederlerdi. Yanında çalıştıkları ağanın her türlü işini yapan hizmetkarlar, onun verdiği yemekle beslenir, gösterdiği odada yatar, sezon sonunda ise ondan bir takım elbise, ayakkabı ve ücretini alarak ağanın yanından ayrilırd $1^{18}$.

\footnotetext{
${ }^{15}$ Defterlerde hane reislerinin meslekleri erbab-ı ziraatden idüğü şekliyle belirtilmiştir. Bk. BOA. NFS.d. No: 1768

16 Ö. Asım Aksoy, Türkiye Halk Ağzından Derleme Sözlüğü, Türk Dil Kurumu Yayınları, c. 4, Ankara, 2009, s.2889. Öte yandan defterde kizir olarak kaydedilen bu kişi 28. Hanenin reisi Koca Oğlu Halil'dir. Her hangi bir arazisi olmayıp, kizirlikten yıllık geliri 500 kuruş olarak kaydedilmiştir. Bk. BOA. NFS.d. No: 1768.

17 Ö. A. Aksoy, Türkiye Halk Ağzından Derleme Sözlüğü IV, 2009; s. 2889.

18 M. Kılıç, Kömürcü'den Kayaş'a Bir Hayat Hikayesi, 2018, s.87.
} 
Tablo- 3: Meslek Gruplarının Sayısı ve Yüzdelik Dağılımı

\begin{tabular}{|l|c|c|}
\hline \multicolumn{1}{|c|}{ Meslek } & Sayısı & Yüzdelik \\
\hline Çoban & 3 & 11 \\
\hline Erbab-1 Ziraat & 18 & 66,6 \\
\hline Kizir & 1 & 3,8 \\
\hline Hizmetkar & 2 & 7,5 \\
\hline Irgat & 3 & 11 \\
\hline Toplam & 27 & 100 \\
\hline
\end{tabular}

Temettuat defterlerine göre vergi mükellefi olan hane reisleri, bunların meslekleri ve bir senede vermiş oldukları vergi görülmektedir. Bu duruma göre köydeki hane reislerinin hepsi vergi mükellefi olarak değerlendirilmiştir. Bir başka ifade ile köyde yaşayan herkese vergi tahakkuk ettirilmiştir. $\mathrm{Bu}$ hane reislerinden yatalak olan bir kişi olup, bu kişi de vergi mükellefi sayılmıştır. Köyde ilk üçe giren vergi mükellefi hane reisi 533'er kuruş vergi-yü mahsusa vermiştir ${ }^{19}$. En az vergi verenler ise 50'şer kuruşluk vergi ile meslekleri çoban ve hizmetkar olan iki hane reisidir. Diğer hane reisleri bu iki rakamın arasında vergi verdiği görülmektedir. Köydeki toplam vergi-yü mahsusa miktarı 7.134 kuruş olarak hesaplanmıştır.

Tablo- 4: 1844-1845 Yılında Kömürcü Köyü’ndeki Vergi Mükelleflerinin Meslekleri ve Vergi-yü Mahssaları

\begin{tabular}{|l|l|l|c|}
\hline $\mathbf{N o}$ & Hane Reisi & Meslek & Vergi-yü Mahsusa \\
\hline $\mathbf{1}$ & Göde Oğlu Dede & Erbab-1 Ziraat & 533 \\
\hline $\mathbf{2}$ & Çakır Oğlu Hüseyin & Erbab-1 Ziraat & 533 \\
\hline $\mathbf{3}$ & Mahmud Oğlu Seyyid & Erbab-1 Ziraat & 533 \\
\hline $\mathbf{4}$ & Abidin Oğlu Seyyid & Erbab-1 Ziraat & 444 \\
\hline $\mathbf{5}$ & İmam Oğlu İsmail & Erbab-1 Ziraat & 345 \\
\hline $\mathbf{6}$ & Topal Dede Oğlu Osman & Yatalak Hasta & 340 \\
\hline $\mathbf{7}$ & Emir Oğlu Hüseyin & Vefat Etmiş & 332 \\
\hline $\mathbf{8}$ & Küçük Mehmed Oğlu Mehmed & Erbab-1 Ziraat & 286 \\
\hline $\mathbf{9}$ & Abidin Oğlu Dede & Erbab-1 Ziraat & 266 \\
\hline $\mathbf{1 0}$ & Abidin Oğlu Mustafa & Erbab-1 Ziraat & 266 \\
\hline $\mathbf{1 1}$ & Koca Mustafa Oğlu Baba Oğlan & Erbab-1 Ziraat & 256 \\
\hline $\mathbf{1 2}$ & Karenpe(?) Oğlu İbrahim & Erbab-1 Ziraat & 248 \\
\hline $\mathbf{1 3}$ & Amancı Oğlu Seyyid & Erbab-1 Ziraat & 240 \\
\hline
\end{tabular}

19 Hane reisleri için sene-i sabıkada vergi-yü mahsusadan bir senede vermiş olduğu yazıldıktan sonra, kuruş cinsinden miktar yazılmaktadır. Tanzimat idarecileri tarafından örfi vergiler yerine ikame edilen ve an cemaatin vergi, vergi, komşuca alınan vergü, vergi-yi mahsusa gibi isimler verilen bu vergi, köy muhtar ve kocabaşlarıyla zaptiye askerleri tarafından tahsil edilerek muhassıllara teslim ediliyordu. Bu verginin tahsili, 1260 yılına (1844) kadar rûz-ı hızır ve rûz-ı kasım olarak iki taksitte yapılıyordu. Fakat bu iki zamanda vergi tahsilatı için uygun değildi. Bu nedenle bu tarihten sonra verginin çiftçilerden, (ashâb-ı zirâ 'at) ürünün elde edilmesinden sonra, sanayici, tüccar ve esnaftan ise sene içinde sene basından sonuna kadar, taksitler halinde tevziatı ve tahsilatı kararlaştırılmıştır. Bk. T. Güran, Tanzimat Döneminde Osmanlı Maliyesi Bütçeler ve Hazine Hesapları (1841-1861), Ankara 1989, s.145 


\begin{tabular}{|l|l|l|l|}
\hline $\mathbf{1 4}$ & Bektaş Oğlu Halil & Erbab-1 Ziraat & 232 \\
\hline $\mathbf{1 5}$ & Musa Oğlu Baba Oğlan & Erbab-1 Ziraat & 232 \\
\hline $\mathbf{1 6}$ & Hasan Oğlu Ahmed & Erbab-1 Ziraat & 210 \\
\hline $\mathbf{1 7}$ & Osman Oğlu Seyyid & Erbab-1 Ziraat & 195 \\
\hline $\mathbf{1 8}$ & Osman Oğlu Osman & Erbab-1 Ziraat & 195 \\
\hline $\mathbf{1 9}$ & Hasan Oğlu Mehmed & Çoban & 180 \\
\hline $\mathbf{2 0}$ & Tirak Oğlu Baba Oğlu & Irgat & 180 \\
\hline $\mathbf{2 1}$ & Hacı Memiş Ali & Irgat & 180 \\
\hline $\mathbf{2 2}$ & Abidin Oğlu Abdullah & Erbab-1 Ziraat & 170 \\
\hline $\mathbf{2 3}$ & Abidin Oğlu Hüseyin & Erbab-1 Ziraat & 165 \\
\hline $\mathbf{2 4}$ & Hasan Oğlu Ahmed & Çoban & 155 \\
\hline $\mathbf{2 5}$ & Hasan Oğlu Mehmed & Irgat & 142 \\
\hline $\mathbf{2 6}$ & Koca Oğlan Oğlu Halil & Kizir & 106 \\
\hline $\mathbf{2 7}$ & Süleyman Oğlu Memiş & Hizmetkar & 70 \\
\hline $\mathbf{2 8}$ & Deli İbrahim Oğlu Çoban Ali & Çoban & 50 \\
\hline $\mathbf{2 9}$ & Aziz Oğlu Süleyman & Hizmetkar & 50 \\
\hline & TOPLAM & & 7134 \\
\hline
\end{tabular}

Kömürcü Köyü’nde alınan bir diğer vergi ise öşürdür. Öşür Arapça kökenli bir kelime olup, anlamı onda bir demektir. Ancak, terim olarak mutlaka onda bir yerine kullanılmamıştır. Mahsullerin onda birinden alınan vergi olarak bilinen öşür, farklı zamanlarda farklı kalıplara sokularak artmış veya

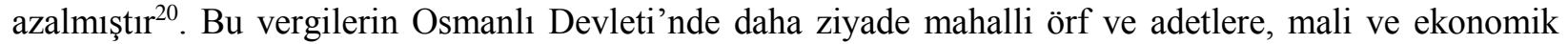
değerlendirmeye dayandığını belirtmek yerinde olacaktır ${ }^{21}$. Kömürcü Köyü'nün, temettuat defterinde; 'aşâr ve rüsûmu olarak sene-i sabıkada bir senede vermiş olduğu ifadesinden sonra ürünler belirtilmiş, altına da nakdî miktar ayrı ayrı yazılmıştır. Bu öşürlere ait aynî miktarlar yazılmamıştır ${ }^{22}$.

Tablo- 5: Kömürcü Köyü’nde Tarım Ürünleri Öşrü ve Miktarı

\begin{tabular}{|l|l|c|c|}
\hline \multicolumn{1}{|c|}{ No } & \multicolumn{1}{|c|}{ Ürün Cinsi } & Miktar (Kuruş) & Öşür Veren Hane Sayısı \\
\hline $\mathbf{1}$ & Hınta (Buğday) & 166 & 16 \\
\hline $\mathbf{2}$ & Şa'ir (Arpa) & 102 & 15 \\
\hline $\mathbf{3}$ & Burçak & 18 & 15 \\
\hline
\end{tabular}

Tabloda da görüldüğü üzere, hane bazında değerlendirmeye alındığı zaman, en fazla öşür verilen ürünün buğday olduğu görülmektedir. 29 haneden 16 hane buğday öşrü vermiştir. Miktar olarak verilen öşür ise, 166 kuruştur. Bir sonraki ürün arpadır. Arpa 15 hane reisi tarafından verilmiş olup, miktarı 102 kuruştur. Bunlardan başka yine 15 hane reisi tarafından toplam 18 kuruş burçak öşrü verilmiştir. $\mathrm{Bu}$ ürünlerin aynî değerleri verilmediği için köyde hangi üründen ne miktar öşür verildiği tespit edilememiştir.

\footnotetext{
20 Z. Karamürsel, Osmanlı Mali Tarihi Hakkında Tedkikler, 1989, s. 165.

21 Ö. L. Barkan, "Öşür" islam Ansiklopedisi IX, 1965, s. 485.

22 BOA. NFS.d. No: 1768.
} 
İncelediğimiz dönemde Kömürcü Köyü'nde, küçükbaş hayvanc1lık olarak keçi ve koyun yetiştirilmektedir. Bu hayvanlardan âdet-i ağnam ${ }^{23}$ yer almamaktadır. Âdet-i ağnam, Osmanlı Devleti'nde, koyun ve keçi gibi küçükbaş hayvanlardan alınan verginin adıdır ${ }^{24}$. Öte yandan Kömürcü köyünde 9 hane reisi âdet-i ağnam vermiştir. Bunların verdikleri toplam âdet-i ağnam 49,5 kuruş olarak deftere kaydedilmişstir.

Kömürcü Köyü'nde halkın arazi kullanımına gelince, Osmanlı döneminde bir ailenin mülkiyetine ait olup olmadığına bakılmaksızın, nadasa bırakılan topraklar ile ekilen toprakların yüzölçümlerine göre tarım işletmeleri üç sınıfta değerlendirmeye alınmıştır. Yüzölçümleri 10 dönümden ${ }^{25}$ az olanlar küçük, 10-50 dönüm arasında olanlar orta, 50 ve daha büyük olanlar ise büyük işletme olarak tasnif edilmiştir ${ }^{26}$. Temettuat verilerine göre Kömürcü Köyündeki hanelerin arazi miktarlarının tamamı 15 dönüm ile 30 dönüm arasında değişmektedir. Dolayısıyla işletmelerin tamamı orta büyüklükteki işletmeler sınıfına girmektedir.

Köyde kayıtlı olan arazi 320 dönümdür. Toplam 29 haneden 18 hanenin arazisi bulunurken, 11 hanenin herhangi bir arazisi kayıtlı değildir. Köydeki arazi büyüklüğü 15 ile 30 dönüm arasında değişmektedir. Köydeki arazilerin tamamına yakını mezrû' tarla olarak kaydedilmiştir. Bunun yanında iki hane için toplam 5 zeytin fidanı kaydedilmiş ve bunlardan 22 kuruş gelir kaydedildiği belirtilmiştir. Fakat bunlar için ayrıca bağ, bahçe gibi her hangi bir arazi çeşidi kaydedilmemiştir.

Tablo-6: Kömürcü Köyündeki Arazi Sahipleri Bilgileri

\begin{tabular}{|l|c|}
\hline Arazisi Olan & 18 Hane \\
\hline Arazisi Olmayan & 11 Hane \\
\hline Toplam Arazi & 320 Dönüm \\
\hline
\end{tabular}

M.1844 yılı kayıtlarından Kömürcü Köyü’nde yetiştirilen hayvanları kendi içinde tasnif etmek mümkündür. Buna göre köydeki büyükbaş, küçükbaş ve yük ve binek hayvanı olmak üzere 3 gruptan bahsedebiliriz. Kömürcü Köyü’nde 14 büyükbaş, 198 küçükbaş ve 45 yük ve binek hayvanı bulunmaktadır. Bütün bu hayvanların sayısı ise $257^{\prime}$ dir $^{27}$.

Tablo-7: Kömürcü Köyü Hayvan Grupları ve Oranları

\begin{tabular}{|l|c|c|}
\hline \multicolumn{1}{|c|}{ Hayvan Gurubu } & Adet & Oran(\%) \\
\hline Büyükbaş & 14 & 5,44 \\
\hline Küçükbaş & 198 & 77,04 \\
\hline Yük ve Binek & 45 & 17,5 \\
\hline Toplam & 257 & - \\
\hline
\end{tabular}

\footnotetext{
${ }^{23}$ Ağnam, kelime olarak, Arapça'da koyun anlamına gelen "ganem" kelimesinin çoğuludur. Bk. Ş. Sami, Kamus-ı Türkî, 2015, s.221

24 M. Z. Pakalın, Osmanlı Tarih Deyimleri ve Terimleri Sözlüğü I, 1993, s. 20.

25 Dönüm, Osmanlılarda kullanılan temel arazi ölçü birimidir. Genellikle geniş adımlarla yürüyen birinin adımı ile 40x40 adım karelik bir yüzölçümü birimini ifade eder. Buna "örfi dönüm” adı verilir. Ancak adım aralığı kişiden kişiye değiştiği için, her adım bir mimar arşını (yaklaşık 75, 78 cm.) esas alan bir ölçü birimi ile sabitlenmiş ve buna "şer’î dönüm" adı verilmiştir. Buna göre dönüm yaklaşık olarak 916,8 m² veya 919,302 m²'lik bir araziyi göstermektedir. Bkz. F. Emecen, "Dönüm”, Diyanet İslam Ansiklopedisi, C.IX, İstanbul 1994, s. 521.

${ }^{26}$ T. Güran, XIX. yüzyıl Osmanlı Tarımı, 1998, s.82.

27 BOA. NFS.d. No: 1768.
} 
Yüzdelik olarak en çok hayvan sayısını küçükbaş hayvan grubu oluşturmakta olup, bütün hayvan sayısına oranı \% 77.04'tür. \%17.05 ile ikinci sırada yük veya binek hayvan olarak kullanılanlar oluşturur. Defterde en az orana sahip hayvan grubu büyükbaş hayvanlardır. Bunların toplam içerisindeki oranı, \% 5,44'tür. Büyükbaş hayvan grubuna dahil edilen hayvanlar; sağman inek ve danadır. İnekler sağmal inek olarak, danalar ise bir yaşıında dana olarak kaydedilmiştir ${ }^{28}$.

Tablo-8: Kömürcü Köyünde Büyükbaş Hayvan Sayıları ve Sahip Olan Hane Sayıları
\begin{tabular}{|l|c|c|}
\hline Cinsi & Sayısı & Sahip Olan Hane Sayısı \\
\hline Sağmal inek & 12 & 11 \\
\hline Dana & 2 & 2 \\
\hline Toplam & 14 & - \\
\hline
\end{tabular}

Kömürcü Köyü'ndeki büyükbaş hayvan sayısının toplamı 13'tür. Bunlardan 11 tanesi sağmal inek 2 tanesi de danadır. Hane bazında değerlendirildiği zaman 11 hanenin en az bir tane sağman ineğe sahip olduğu görülmektedir. 29 haneli bir köyde 11 hanenin ineği olması köyde büyükbaş hayvancılığın çok yaygın olmadığını göstermektedir. 2 hanede en az bir dana bulunmaktadır.

Köydeki küçükbaş hayvan sayısı ise 198'dir. Bu gruba keçi, koyun, koç, kuzu ve oğlak dâhil edilmiştir. Köyde 110 koyun, 23 keçi, 1 koç, 53 kuzu ve 11 oğlak bulunmaktadır. Bunlardan koyuna sahip hane sayıs1 14 , keçiye sahip hane sayısı 3, koça sahip hane sayısı 1, kuzuya sahip hane sayısı 10 ve oğlağa sahip hane sayısı 3 olarak kaydedilmiştir. Bu hayvanların eti, sütü, derisi ya da kıllarının nasıl değerlendirildiği ile ilgili herhangi bir bilgi bulunmamaktadır. Ancak, sağmal koyunlara ve keçilere gelir kaydedilmiştir.

\begin{tabular}{|} 
Tablo-9: Kömürcü Köyünde Küçükbaş Hayvan Sayıları ve Sahip Olan Hane Sayıları \\
\hline Cinsi & Adet & Sahip Olan Hane Sayısı \\
\hline Koyun & 110 & 14 \\
\hline Keçi & 23 & 3 \\
\hline Koç & 1 & 1 \\
\hline Kuzu & 53 & 10 \\
\hline Oğlak & 11 & 3 \\
\hline Toplam & 198 & \\
\hline
\end{tabular}

Yük ve binek hayvanı olarak değerlendirmeye tabi tuttuğumuz hayvanlar öküz ve merkeptir. Bunların sayısının toplamı $45^{\prime}$ tir. Bu gruptaki sayısı en çok olan hayvan öküzdür. Öküz sayısı 30 olup, 16 hanenin en az bir öküzü bulunmaktadır. Öküz, sanayinin gelişmediği dönemlerde, temel geçim kaynağı ziraat olan toplumlarda büyük önem arz etmektedir. Çünkü tarımsal hayatın bütün safhalarında öküz önemli yer tutmaktaydı. Bu bağlamda, çift sürmek, yük taşımak, hasat etmek hep öküzlerle yapılmaktaydı. İncelediğimiz dönemde temel geçim kaynağı Kömürcü Köyü’nde de öküz sayısının diğer hayvanlara göre fazla sayıda olması normal bir durumdur. Bundan başka köyde 12 tane de merkep bulunmaktadır. 
Tablo-10: Kömürcü Köyünde Yük ve Binek Sayıları ile Sahip Olan Hane Sayıları

\begin{tabular}{|l|l|l|}
\hline Cinsi & Sayısı & Sahip Olan Hane Sayısı \\
\hline Koşum Öküzü & 30 & 16 \\
\hline Merkep & 15 & 12 \\
\hline Toplam & 45 & - \\
\hline
\end{tabular}

1844 yılı kayıtlarından köyün toplam gelirinin 26.685 kuruş olduğu anlaşılmaktadır. Bu gelirin büyük bir kısmı herhangi bir açıklama belirtilmeden ticaretinden olarak kaydedilen gelirlerdir. Bu gelir 12.885 kuruş olup, toplam gelire oran1 \% 48.29'dur. Bunu 7.056 kuruşla tarım gelirleri takip etmekte olup, bunun oranı ise \% 26.44'tür. Bundan başka kişilerin beden gücü ile elde ettikleri gelirler bulunmakta olup, çobanlık, kizirlik, hizmetkarlık ve 1rgatık gelirleri bulunmaktadır. Bunların içerisinde en yüksek değere sahip \% 7.68 ile çobanlık gelirleri başı çekmektedir. Bunu \% 6.93 ile 1rgatlık gelirleri takip etmektedir. Kizirlik ise tek bir hane reisinin geliri olup 500 kuruş ile \% 1.87 orana sahiptir. Köyün hayvancılık gelirleri ise 1.074 kuruş olup, \% 4.02 'lik bir orana sahiptir. ${ }^{29}$

\begin{tabular}{|l|c|c|}
\hline \multicolumn{3}{|c|}{ Tablo-11: Kömürcü Köyü'nün $\mathbf{1 8 4 4}$ Yılı Gelirleri ve Yüzledik Dağılımı } \\
\hline Gelir & Gelir Miktarı & Yüzdelik Dağılım \\
\hline Çobanlık & 2050 & 7,68 \\
\hline Kizirlik & 500 & 1,87 \\
\hline Hizmetkarlık & 1270 & 4,76 \\
\hline Irgatlık & 1850 & 6,93 \\
\hline Ticaret & 12885 & 48,29 \\
\hline Hayvancılık & 1074 & 4,02 \\
\hline Tarım & 7056 & 26,44 \\
\hline Toplam & $\mathbf{2 6 6 8 5}$ & $\mathbf{1 0 0}$ \\
\hline
\end{tabular}

Kömürcü Köyü'nde tarım ve hayvancılık en önemli geçim kaynaklarıdır. Hayvancılık gelirlerinin türü defterlerde tam olarak verilmemiştir. Bu bağlamda büyükbaş ve küçükbaş hayvanlardan sağmal olarak nitelendirilen hayvanlara yıllık gelir kaydedilmiştir. Osmanlı Devleti'nde XIX. yüzyılın başlarında bölgelerdeki farklılarıla birlikte, bir inek yılda 192-770 litre ve koyun ve keçi ise bir yılda 51-77 litre arasında süt vermektedir ${ }^{30}$. Geleneksel Anadolu kültüründe hayvanlardan elde edilen sütün değişik kullanım yöntemleri bulunduğu bir gerçektir. Bu anlamda direk süt kaynatılarak tatlandırıcı ile birlikte kahvaltılarda ve diğer ögünlerde tüketilmektedir. Ayrıca, tereyağı, peynir, lor ve yoğurt da yapılmaktadır. Yine XIX. yüzyıl başlarında 20 litre inek sütünden $1 \mathrm{~kg}$. tereyağ $1,5.5$ litre koyun sütünden $1 \mathrm{~kg}$. peynir elde etmek mümkündür. Bu bilgilerden yola çıkarak bir inekten yılda $38.5 \mathrm{~kg}$. yağ ve bir koyundan da $12,5 \mathrm{~kg}$. peynir elde edilebilmiştir. Dokumacılığın hammaddesi olan yün veya yapağı koyundan elde edilen bir üründür. Keçiden ise kıl elde edilmektedir. Yine XIX. yüzyılda bir koyundan yılda 950 gram yün elde edilirken, k1l keçisinden 340 gram k1l elde edilmektedir ${ }^{31}$.

\footnotetext{
${ }^{29}$ BOA. NFS.d. No: 1768.

30 T. Güran, XIX. yüzyıl Osmanlı Tarımı, 1998, s. 104.

31 T. Güran, XIX. yüzyıl Osmanlı Tarımı, 1998, s. 104.
} 
Tablo-12: 1844 Yılında Kömürcü Köyünün Tahmini Hayvan Hasılatı

\begin{tabular}{|l|l|l|l|l|l|l|}
\hline \multicolumn{1}{|c|}{ Türü } & Sayısı & $\begin{array}{l}\text { Tahmini Yıllık } \\
\text { Süt (Litre) }\end{array}$ & $\begin{array}{l}\text { Tahmini Yıllık } \\
\text { Tereyağı (Kg.) }\end{array}$ & $\begin{array}{c}\text { Tahmini Yı̀nir (Kg.) } \\
\text { Peynik }\end{array}$ & $\begin{array}{c}\text { Yün } \\
\text { Yapağı (Kg.) }\end{array}$ & Kıl \\
\hline Sağmal inek & 12 & $2304-9240$ & 462 & - & - & - \\
\hline Sağmal davar & 110 & $5610-8470$ & - & 1375 & 104,5 & - \\
\hline Keçi & 23 & $1173-1771$ & - & 287 & - & 7,8 \\
\hline
\end{tabular}

Sanayi öncesi bir tarım toplumunun bütün özelliklerini, Osmanlılarda görmek mümkündür. İncelediğimiz deftere göre köyün ekonomik yapıyı belirleyen en önemli unsur ziraattır. Bu çerçevede, diğer sanayi öncesi tarım toplumlarında olduğu gibi, milletlerarası, bölgeler arası ve bölge-içi ticaret, kentsel ekonomik faaliyetler, hayvancılık vb. de ekonomide önemli rollere sahipti. Bu durum, tarımın temeli olan toprak yönetimin sağlam temellere oturtulması lüzumunu hissettirmiştir. Bilindiği gibi Osmanlı Devleti'nde toprak rejimi dirlik sistemine dayanmaktaydı. Bu sistem, tarihi temelleri, hukuki dayanağı, sosyal desteği, askeri gücü olan ve siyasi iradeyi toprağa hâkim kılan bir sistemdi.

Osmanlı'da toprakların büyük bir kısmı miri arazi olup sonuçta mülkiyeti devlete aitti ${ }^{32}$. Çıplak mülkiyeti devlete ait olan arazi, işletilmek üzere bir bedel karşılığında köylüye verilirdi. Köylü kendi ihtiyacı kadar toprağı, devlet görevlisi olan sipahiden tapu resmi olarak bilinen peşin kira ödeyerek kiralardı. Eğer kiralama şartlarına uymayacak olur ise, kiraladığı toprağın elinden alınmasına ve ödediği resmin yanmasına razı olurdu. Köylü, işlediği toprak karşılığında onda bir ile onda beş oranındaki bir payı devlete verirdi. Köylü, toprağı üç yıl boş bıraktığı takdirde, toprak elinden alınır ve bir başkasına verilirdi. Toprak, babadan oğula mülk şeklinde geçer, erkek çocuk olmaması durumunda erkek kardeşe veya yakın akrabalara yeniden kiralanırd1.

1844 yılına ait kayıtlarına göre küçük sayılabilecek bir köy olan Kömürcü Köyü’nün ekonomisini büyük oranda tarım oluşturmaktadır. Bu tarihte köyün tarımsal faaliyetleri hakkında en detaylı bilgiler temetettuat defterlerinde yer almaktadır. Ancak, temel olarak temettuat defterleri istatistikî bilgi veren defterler değildir. $\mathrm{Bu}$ sebeple, tarımsal faaliyetler hakkında direk bilgiler elde etmek mümkün olamamaktadır.

Temettuat defterinde hane reislerinin ne kadar tarım ürünü yetiştirdiği bilgisine yer verilmemiştir. Ancak, hangi hane reisinin, hangi üründen ne kadar öşür verdiği, hem aynî hem de nakdî olarak belirtilmiştir. Ancak, incelemiş olduğumuz defterde öşürlerin aynî miktarları verilmemiştir. Hal böyle olunca, üretim miktarını tespit etmek mümkün olmamıştır. Kömürcü Köyü’nde yetiştirilen ürünler 3 çeşit olup, bunlar buğday (hınta), arpa (şa'ir) ve burçaktır. Bunun yanında iki hane tarafından da zeytincilik yapilmaktadir ${ }^{33}$.

\section{Aile Hayatı}

Nüfus Defterleri ve Temettuat Defterlerinde Kömürcü Köyü’nün M.1842 ve M.1844 yıllarına ait aile hayatı hakkında ipuçları bulmak mümkündür. Kadın nüfus kaydedilmediği için, birden fazla evlilik yapılıp, yapılmadığı hususunda herhangi bir bulunmamaktadır. Ancak, köyde 1 hane reisinin üvey oğlu anlamına gelen oğulluğ $u$ kaydı düşülmüştür. Bu durum köyde birden fazla evlilik yapan kişilerin var olabileceğini göstermektedir.

Köydeki aile yapısına baktığımız zaman, çekirdek aile diyebileceğimiz bir yapının hakim olduğu görülmektedir. Çünkü incelediğimiz defterde, hane reislerinin 25 hane reisinden 20 tanesinin sadece oğlu

\footnotetext{
32 Ö. L. Barkan, “Imparatorluk Devrinde Toprak Mülk ve Vakıfların Hususiyeti”, Türkiye’de Toprak Meselesi, Toplu Eserler I 1980, s. 250.

33 BOA. NFS.d. No: 1768.
} 
veya oğulları ile yaşadığı görülmektedir. 1 hane reisinin ise kardeşleri ile beraber yaşadığı görülmektedir. Bu hane reisi 17 yaşında olup, yaşları 3 ila 12 arasında değişen 4 kardeşi ile yaşamaktadır. Torunları ve oğulları ile beraber yaşayan hane reisi sayısı ise 3'tür. Bunun yanında bir hane reisinin evinde yeğeni de yaşamaktadır.

\begin{tabular}{|l|c|}
\hline Tablo-13: Kömürcü Köyü Nüfus Defteri’nde Hane Reislerinin Kayıt Şekli & Sayı \\
\hline Kayıt Şekli & 4 \\
\hline Sadece Kendisi Kaydedilen & 13 \\
\hline Oğlu/Oğulları ile kaydedilen & 1 \\
\hline Kardeşi ile Kaydedilen & 2 \\
\hline Kardeşi ve Oğlu İle Kaydedilen & 1 \\
\hline Üvey Oğlu İle Kaydedilen & 1 \\
\hline Yeğeni ile Kaydedilen & 3 \\
\hline Oğulları ve Torunları ile Kaydedilen
\end{tabular}

Nüfus defterleri çocuk sayısı hususunda da bilgi vermektedir. Defterde $O \breve{g} l u$ olarak kaydedilen kişi sayısı 33'tür. Nüfus defterlerine göre iki hane reisinin dört oğlu bulunmaktadır. Kömürcüde üç oğlu olan hane reisi üç iken, iki oğlu olan hane reisinin sayısı ise yine üçtür. Köyde genelde her hane reisinin tek oğlu bulunmakta olup, bir oğlu olan hane reislerinin sayısı da 10'dur. Köydeki altı hane reisinin ise erkek çocuğu kaydedilmemiştir. Bir hane reisinin ise erkek çocuğunun bulunduğu, bu oğlun arkasında bir erkek çocuk bırakarak vefat ettiği anlaşılmaktadır. Çünkü bu hane reisinin erkek çocuğu kaydedilmiş, torunu olduğu belirtilmiştir ${ }^{34}$.

Tablo-14: Kömürcü Köyü’ndeki Erkek Çocuk Sayısı

\begin{tabular}{|c|c|}
\hline Erkek Çocuk Sayısı & Hane Sayısı \\
\hline 4 & 2 \\
\hline 3 & 3 \\
\hline 2 & 3 \\
\hline 1 & 10 \\
\hline Erkek Çocuksuz & 6 \\
\hline Diğer & 1 \\
\hline
\end{tabular}

Nüfus defterlerinde kayıtlı bütün kişilerin yaşları tabloda verilmiştir. Bu bilgiler 1şı̆̆ında M.1842 yılında Kömürcü Köyü'nde yaşayan erkeklerin yaşları hakkında net bilgilere ulaşmak mümkün olmuştur. Buradan hareketle, nüfusun ortalama yaşı hakkında tespitler yapılabilme imkânını elde ederken, kişilerin ortalama ömürleri hakkında tahminler de yürütülmüştür.

Kömürcü Köyü’nde yaşayan bütün erkekler göz önünde alındığında 75 kişinin ortalama yaşı 25,41 olarak hesaplanır. Buna göre, incelediğimiz tarihte Kömürcü Köyü’nün nüfus özelliklerine bakıldığı zaman, genç bir nüfusa sahip olduğunu söylemek mümkündür. Yine defterlerdeki nüfus verilerinden hareketle Kömürcü Köyü'ndeki erkeklerin hangi yaş aralıklarında yoğunlaştığını ve hangi yaş grubunun hâkim unsur olduğunu tespit mümkündür.

${ }^{34}$ BOA. NFS.d. No: 1768. 
Tablo-15: 1842 Yılında Kömürcü Köyü’nde Yaşayan Erkeklerin Yaş Dağılımı

\begin{tabular}{|c|c|c|}
\hline Yaş Aralı̆̆ı & Sayısı & Yüzdelik Oran \\
\hline $1-5$ & 13 & 17,33 \\
\hline $6-10$ & 16 & 21,34 \\
\hline $11-15$ & 5 & 6,67 \\
\hline $16-20$ & 6 & 8 \\
\hline $21-25$ & 5 & 6,67 \\
\hline $26-30$ & 2 & 2,67 \\
\hline $31-35$ & 6 & 8 \\
\hline $36-40$ & 3 & 4 \\
\hline $41-45$ & 3 & 4 \\
\hline $46-50$ & 4 & 5,33 \\
\hline $51-55$ & 1 & 1,33 \\
\hline $56-60$ & 5 & 6,67 \\
\hline $61-65$ & 1 & 1,33 \\
\hline $66-70$ & 2 & 2,67 \\
\hline $71-75$ & 1 & 1,33 \\
\hline $75+$ & 2 & 2,67 \\
\hline
\end{tabular}

Tabloda da görüldüğü gibi, çocuk olarak kabul edebileceğimiz yaş grubu olan 1-10 yaş grubuna sahip olan kişi sayısı 29'dur. Bunun yüzdelik oranı \% 38.67'dir. En kalabalık yaş grubu da bu gruptur. 11-20 yaş grubunda 11 kişi olup, bunun oranı ise \%14,67'dir. 21-30 yaş grubunda kayıtlı kişi 7 (\% 9), 31-40 yaş grubunda kayıtlı 9 (\% 12), 41-50 yaş grubunda 7 kişi (\% 9,33), 51-60 yaş grubundaki kişi 6 (\% 7), 61-70 yaş grubundaki kayıtlı kişi $3(\% 4)$ ve $71-80$ yaş grubundaki kişi sayısı da 3 (\% 4)'tür. 80 yaş üzerinde 2 kişi bulunmaktadır.

\section{Sonuç}

1530 tarihli Ankara Muhasebe Defterinde Kömürcü Cemaati olarak kaydedilen yerleşim yeri XIX. yüzyılda köy olarak karşımıza çıkmaktadır. Temettuat defterinde 29, nüfus defterinde ise 75 erkek nüfusu kayıtlıdır. Yine temettuat defterine göre köyde 18 kişi erbab-1 ziraat kaydedildiğinden köylünün kayda değer bir kısmının tarımla uğraştığı anlaşılmaktadır. Kömürcü'de en fazla vergiyi tarımla uğraşanlar ve 1rgatlar vermektedir. En az vergiyi ise 50'şer kuruşla çoban ve başka köylerde ağaların yanında çalışan hizmetkarlar vermektedir. Köyde hizmet sektörü olarak bahsedebileceğimiz 1rgatlar, hizmetkarlar ve başkasının hayvanlarını güden paralı çobanların oranı \%28.50'dir ve bu azımsanacak bir rakam değildir. Kısaca hizmet sektörü olarak ifade ettiğimiz ırgatlar, hizmetkarlar ve çobanlar; köy halkının günlük işler için yakın mesafelere gidip geldiklerini ortaya koymaktadır. Bu durumun altında yatan başlıca sebep yine köyün, yeterli ekonomik kaynaklara sahip olmamasıdır.

Diğer taraftan köylüler çoğunlukla buğday, arpa, burçak ekerek vergilerini vermektedirler. İncelediğimiz dönemde köyde sulu tarım yapılmadığından yerleşim yeri tipik bir Anadolu yerleşimidir. Köydeki şahıs isimleri açısından bakıldığında, en fazla Mehmed, Ali ve Mustafa isimleriyle karşılaşılmaktadır. Sülale isimlerinde ise; Abidinoğulları (5 hane), Hasanoğulları (4 hane) olarak öne çıkmaktadır. Nüfus defterindeki özellikle Hasanoğulları lakabı, Karahasan ile Kömürcü köyleri halklarının artmasıyla birbirinden ayrıldığını ortaya koymaktadır. 
Arazi bakımından tarımla uğraşan 18 hanenin 320 dönüm arazisi vardır. Bu miktar arazi, Anadolu ortalamasının altındadır. Bahsedilen bu 18 haneden 16'sının 30 koşum öküzü vardır. Dolayısıyla ailelerin büyük oranda tarımla meşgul olduğu göze çarpmaktadır. Diğer yandan 11 hanenin ne tarım hayvanından ne de tarım arazisinden bahsedilmektedir.

Kömürcü Karyesi'nde küçükbaş koyun yetiştiriciliği yaygın olmakla birlikte, her ailenin sütünden faydalandığı birer ineği de vardır. İstatistik açısından köyün arazilerinin verimsizliği ve yetersizliği hayvancılığın sınırlı olmasını da dahil edersek ekonomik faaliyetleri bakımından köyün yeterince gelişemediğini köyde yaşayanların bir süre sonra daha fazla hizmet sektörlerine kayacağını ortaya koymaktadır. Köyün belki de en ilginç tablosu yaş dağılımında karşımıza çıkmaktadır. Buna göre 1-25 yaş aralığında köyde 45 kişi (yani, \%60,01) kayıtlıdır. Bu durum nüfusun hızla artmakta olduğunu istatistiki olarak ortaya koyduğundan köylülerin zamanla iş bulmak için metropole doğru gitmelerini engelleyemeyecektir.

\section{Bibliyografya}

\section{Defterler}

Kömürcü Köyü Temettuat Defteri: Başbakanlık Osmanlı Arşivi (BOA. ML.VRD.TMD.d. 292)

Ankara Vilayeti Bala Kazası Nüfus defteri: Kömürcü Karyesi Kısmı (BOA. NFS. d. 1768)

\section{Basılı eserler}

Adıyeke, N. (2000). “Temettüât Sayımları ve Bu Sayımları Düzenleyen Nizamnâme Örnekleri”, OTAM XI, (2000), 769-787.

Aksoy, Ö. A. (2009). Türkiye Halk Ağzından Derleme Sözlüğ̈̈ IV, Ankara: Türk Dil Kurumu Yayınları.

Barkan, Ö. L. (1965). “Öşür” İslam Ansiklopedisi IX, Ankara, 485.

Barkan, Ö. L. (1980). “İmparatorluk Devrinde Toprak Mülk ve Vakıfların Hususiyeti”, Türkiye’de Toprak Meselesi, Toplu Eserler I, 249-280.

Çınar, H.- İ. Kıvrım. (2018). 1842 Tarihli Çubuk Kazası Nüfus Defteri, Ankara: Çubuk Belediyesi Yayınları.

Emecen, F. (1994). “Dönüm”, Diyanet Íslam Ansiklopedisi IX, 521.

Erdoğan, A. (2008). Adım Adım Ankara, Ankara: Büyükşehir Belediyesi Yayınları.

Erdoğan, H. (2005). “820 Numaralı Temettuat Defterine Göre Tanzimat'ın İlk Yıllarında Mucur ve Hacıbektaş’ın Demografik Yapısı ve Sosyal Durumu” GÜ, Kırşehir Ĕgt. Fak. 6(1), 95-102.

Ergenç, Ö. (1980). “XVII. yüzyı1 Başlarında Ankara’nın Yerleşim Durumu Üzerine Bazı Bilgiler”, Osmanlı Araştırmaları I, Ankara, 85- 108.

Ergenç, Ö. (1995). XVI. yüzyılda Ankara ve Konya, Ankara: Ankara Enstitüsü Vakfı Yayınları.

Güran, T. (1998). XIX. yüzyıl Osmanlı Tarımı, İstanbul: Eren Yayınları, 81-82.

Güran, T. (1989). Tanzimat Döneminde Osmanl Maliyesi Bütçeler ve Hazine Hesapları (1841-1861), Ankara: Türk Tarih Kurumu Yayınları.

Güran, T. (2000). “XIX. yüzyıl Temettuat Tahrirleri”, Osmanlı Devleti’nde Bilgi ve Ístatistik, (Der. Halil İnancık, Şevket Pamuk), 73-95. 
İnalcık, H- Ş. Pamuk. (2001). Osmanlı Devleti'nde Bilgi ve İstatistik, Ankara: Başbakanlık Devlet İstatistik Enstitüsü Yayınlar1, 35-50.

İnalcık, H. (1996). Osmanlı İmparatorluğu'nda Toplum ve Ekonomi, İstanbul: Eren Yayınları.

Karamürsel, Z. (1989). Osmanlı Mali Tarihi Hakkında Tedkikler, Ankara: TTK Yayınları.

K1lıç, M. (2018). Kömürcü'den Kayaş'a Bir Hayat Hikayesi, Ankara.

Köç, A. (2012). "Ankara'da Yakub Abdal Zaviyesi'nin İdari Sorunları", Gazi Akademik Bakış XI, 211-236.

Kütükoğlu, (1995). “Osmanlı Sosyal ve İktisadi Tarihi Kaynaklarından Temettuat Defterleri”, Belleten LIX(225), 395-418.

Pakalın, M. Z. (1993). Osmanlı Tarih Deyimleri ve Terimleri Sözlü̆̆̈̈, I, İstanbul: Enderun Yayınları.

Quataert, D. (2008). Anadolu'da Osmanlı Reformu ve Tarım(1876-1908), İstanbul: İş Bankası Yayınları.

Özdemir, R. (1986). XIX. yüzyılın İlk Yarısında Ankara (Fiziki, Demoğrafik, İdari ve Sosyo- Ekonomik Yapısı), Ankara: Kültür ve Turizm Bakanlığı Yayınları.

Öztürk, M. (2018). "Yerel Tarih ve Şehir Tarihçiliğinin Yeri, Önemi ve Bugünkü Durumu”, Uluslararası Gazi Süleyman Paşa ve Kocaeli Tarihi Sempozyumu Bildirileri III, Kocaeli, 421-426.

Özünlü, E. E. (2012). “Ankara Sancağı'nın İdari Yapısı Üzerine Bazı Düşünceler”, Tarihte Ankara Uluslararası Sempozyumu Bildirileri, Ankara, 45-63.

Sami, Ş. (2015). Kamus-ı Türkî, İstanbul: Çağrı Yayınları. 